\title{
СВОБОДА КАК ФИЛОСОФИЯ БОГОЧЕЛОВЕЧЕСТВА (Н. БЕРДЯЕВ)
}

\begin{abstract}
Аннотация. В статье рассматривается идея свободы и кониепиия богочеловечества в понимании Н.А. Бердяева (1874-1948). Филособ полагал, что творческая способность человека и выделяет его из причинно-целевой цепи природного мира и ведет его к самоспасению. С помощью творчества человек выходит за пределы мира необходимости и входит в изарство свободы. Однако, по мысли Бердяева, не детерминизм природного мира является главным врагом свободы личности - объективация является помехой для человека на пути кего свободе. Ранее Бердяев говорил о двойственности человека и о наличии двух миров у человека - мира внутреннего, субъективного и мира внешнего, объективного. В своем определении свободы как метабизического начала Бердяев опирается, прежде всего, на иррационалистическую традицию и интуитивизм в духе Бергсона. Поэтому для понимания и определения феномена свободы нужно действовать не в рамках рационалистической традиции, а опираться на данные нашего духа и внутреннего опыта. Только тогда можно понять утверждение Бердяева о том, ито проблема свободы есть проблема творчества. Эволюиия взглядов Бердяева была такова, что в своих ранних работах он трактовал онтологию как монадологию и понятие бытие сначала не несет в себе ничего отрицательного. Однако постепенно он приходит к мысли необходимости «освобождения» от мира причинности. В его поздних трудах уже возникает идея о противоположности свободы и бытия, а само понятие бытия начинает характеризоваться как «падший мир». При этом свобода стоит как над миром природной детерминации, так и над богом - свобода коренится в «небытии», имеющим более высокий статус чем статус бога.
\end{abstract}

Ключевые слова: психология, свобода, Бердяев, философия, богочеловечество, метафизика, Россия, человек, общество, славянофиль.

\section{1. Судьба и философское развитие Н. Бердяева}

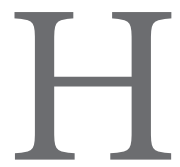
иколай Александрович Бердяев родился 6 (18) марта 1874 г. в дворянской семье в Киеве. Отец его был украинским помещиком, мать происходила из княжеского рода Кудашевых. В юности по настоянию родителей Бердяев поступает в Киевский кадетский корпус, однако, вскоре, не без труда преодолев сопротивление отца и матери, он поступает в 1894 г. на естественный факультет Киевского университета, а через год переводится на юридический факультет. Однако истинным интересом Бердяева стало не право, а философия. Он рано осознает проблемы несправедливости в тогдашнем российском обществе и примыкает к набиравшему тогда силу марксизму. Из-за своих интересов он был даже в 1898 г. арестован, а в 1900-1902 гг. был направлен в ссылку.

Однако даже знакомство в ссылке с А. Луначарским и А. Богдановым все-же не сделали из Бердяева последовательного марксиста: «Жестокий коллекти- визм марксистской теории, а тем более практики, в сочетании с типично российской традицией идейной кружковщины, очень скоро вступили в конфликт с аристократичной по духу и свободолюбивой по природе натурой Николая Александровича»'. Постепенно Бердяев отходит от идей марксизма и его интерес перемещается все в теоретическую абстрактную плоскость. Для более глубокого изучения западной философии он едет в Германию, где в университете г. Гейдельберг он учится некоторое время.

После своей женитьбы на Лидии Трушевой в 1904 г., Бердяев вместе с женой поселяется в Петербурге и начинает заниматься издательской деятельностью в журналах «Новый путь» и «Вопросы жизни». Революция 1905 г. сделала для Бердяева очевидной столкновение «черной» и «красной» анархий, ведущую к безудержному и бессмысленному насилию. Именно эти события, по всей видимости, и вернули его с метафизических высот

\footnotetext{
1 Филиппова Т. Николай Александрович Бердяев // Волкогонова О. Бердяев. М., 2010. С. 6.
} 
к злободневным вопросам политики. Позже сфера его философских интересов будет постоянно перетекать от богословия к идее свободы и творчества и к политическим проблемам современности. Как это часто бывает в философии (вспомним хотя бы известного немецкого философа Эрнста Кассирера, проделавшего эволюцию от «Философии символических форм» К «Мифу о государстве»), жизнь вносит существенные коррективы в даже самые абстрактные метафизические теории, которые Бердяев развивал всю свою жизнь.

Именно во время своей работы в журнале «Новый путь» Бердяев лично знакомится с многими известными русскими мыслителями: Л. Шестовым, В. Брюсовым, В. Розановым, П. Новгородцевым, С. Франком, В. Эрном и другими. Идеи этих философов и повлияли в большой степени на интеллектуальное развитие Бердяева.

После поездки в Париж в 1907-1908 гг. семья Бердяевых обосновывается в Москве. Здесь он снова завязывает ряд очень интересных знакомств и принимает участие в работе «Религиозно-философского общества» им. Вл. Соловьева. Изучение идей православия было продолжено им и в православном кружке М. Новоселова. Очередной вехой в биографии Бердяева стало его сотрудничество с издательством «Путь», выпускавшим труды известных российских мыслителей. Помимо этого, Бердяев готовит совместно с П. Струве и П. Новиковым философские сборники «Вехи» (1909) и «Из глубины» (1918). Во время работы над «Вехами» Бердяев формулирует для себя основные идеи метафизики свободы и в 1911 г. издает свою «Философию свободы». Сразу после этого в Италии он создает также одну из своих главных работ, задавших парадигму его будущих философских исканий, «Смысл творчества».

Как уже было отмечено выше, Бердяев никогда не оставался в стороне от реальных политических событий современности: «С особой чуткостью предвосхищая наступающую эру социально-политических катаклизмов, Бердяев встретил Первую мировую войну и Февраль 1917-го как рубеж старого и нового времени не только в российской, но в мировой истории. «Русская свобода», «Труды и дни», «Утро России», «Христианская мысль», «Русская мысль», «Вопросы философии и психологии», «Биржевые ведомости» и т.д. - его статьи постоянно присутствовали на страницах этих и других популярных периодических изданий того времени»².

Во времена этих сильнейших исторических потрясений Бердяев создает свою книгу «Судьба России» она была написана до Октябрьской революции 1917 г., но вышла в свет лишь в 1918 г., где он пытается доказать

2 Там же. С. 11. особую роль России в геополитическом пространстве Евразии как моста между Востоком и Западом. Говоря о недостаточной интеграции России с западноевропейскими государствами, в качестве преодоления такого положения вещей он предлагает развивать «творческий дух» нашего народа.

После Октябрьской революции Бердяев работает во Всероссийском союзе писателей и начинает читать лекции в Московском университете, где он имеет большой успех среди студентов. Именно в это время он создает свои работы «Философия неравенства»³, «Смысл истории» и «Миросозерцание Достоевского», где философ выражает свое неприятие к режиму диктатуры пролетариата. Результатом такой деятельности стал вызов Бердяева на допрос к самому Дзержинскому и привлечение его к принудительным работам. Из сегодняшней исторической перспективы можно сказать, что было несколько удивительно, что революционные власти России позволили Бердяеву в течение последующих пяти лет после Октябрьской революции оставаться и активно работать в стране - вплоть до августа 1922 г., когда Бердяев был арестован по обвинению в антисоветской деятельности. Целую неделю Бердяев провел в заточении на Лубянке, после чего его выпустили, обязав выехать за пределы России - в сентябре 1922 г. он был выслан в Германию.

И хотя Бердяеву было нелегко - прежде всего, психологически - в эмиграции, он и там окунается в активную работу: в 1922 г. он создает в Берлине Религиозно-философскую академию, преподает и содействует Русскому студенческому христианскому движению. В это время в Германии Бердяев завязывает контакты с О. Шпенглером и М. Шелером. После Берлина в 1924 Бердяев переезжает в Париж, где он воссоздает Религиозно-философскую академию и журнал «Путь» ${ }^{4}$, а также занимает пост редактора в издательстве YMCAPress, где и была опубликована значительная часть его работ, созданных в эмиграции. Именно в пригороде Парижа Кламар Бердяевым и были написаны работы его позднего периода: «О назначении человека», «Истоки и смысл русского коммунизма», «Опыт эсхатологической метафизики. Творчество и объективация», «Самопознание», «Царство Духа и Царство Кесаря», «Экзистенциальная диалектика божественного и человеческого».

Во время своей вынужденной эмиграции Бердяев постоянно задавался мыслями о своем возвращении на родину, однако внутренняя обстановка в тогдашнем СССР останавливала его от такого решительного шага.

\footnotetext{
3 Книга была опубликована в Берлине лишь в 1923 г.

4 Журнал «Путь» издавался с 1925 по 1940 гг.
} 


\section{Психология и психотехника 7(58) • 2013}

Также много мрачных мыслей навевал ему и тот факт, что его философские работы позднего периоды были совершенно неизвестны в России: «Я очень известен в Европе и Америке, даже в Азии и Австралии, переведен на много языков, обо мне много писали. Есть только одна страна, в которой меня почти не знают это моя родина. Это один из показателей перерыва традиции русской культуры. После пережитой революции вернулись к русской литературе, и это факт огромной важности. Но к русской мысли еще не вернулись. Философия остается в очень неблагоприятном положении; свободы мысли нет» ${ }^{5} .23$ марта 1948 г. в Кламаре Бердяев умирает прямо за письменным столом во время работы над книгой «Царство Духа и Царство Кесаря».

\section{2. Свобода как философия богочеловечества}

Исходным пунктом и целью всей философии Бердяева была человеческая личность как нечто уникальное и не сводимое лишь к эмпирическому описанию человека как природного существа. Бердяев разводит понятия личности и индивидуума. Так, если индивидуум «детерминирован» обществом и природой, то личность - это духовная реальность, главной характерной чертой выступает свобода: «личность, по Бердяеву, не просто обладает свободой, она и есть сама свобода» ${ }^{6}$. Пытаясь более конкретно определить, что же такое личность, Бердяев вводит понятие «творческого акта» вместо традиционных понятий субстанции (монады), бытия или разума.

Бердяев критикует - вполне в духе традиции славянофилов - современную западную философию, которая пошла по «отвлеченно-рационалистическому» пути, тогда как проблема свободы может быть решена лишь для посвященных в тайны христианства, лишь «в акте веры, в котором дается не призрачная, а подлинная реальность и конкретный гнозис. [...] Христианский гнозис приводит к трансцендентному реализму, к конкретному персонализму, к билософии свободы. Свобода, прежде всего свобода - вот душа христианской философии и вот что не дается никакой другой, отвлеченной и рационалистической философии» ${ }^{7}$.

Для Бердяева догматы христианства - это не спекулятивные метафизические теории, а факты и «живой опыт». Задача философии, направленная на

\footnotetext{
Бердяев Н. Самопознание. Опыт философской автобиографии. Париж, 1949. С. 364.

6 Гайденко П.П. Владимир Соловьев и философия Серебряного века. М., 2001. С. 303.

7 Бердяев Н. Философия свободы. М., 2007. С. 15.
}

раскрытие человеческим разумом вселенской истины может быть только соборным и сверхиндивидуальным делом. Философия только тогда обретет свою свободу мышления, когда она будет освобождена церковью от царства рабства и мира необходимости.

В противовес традиции западноевропейского рационализма, Бердяев критикует протестантизм за то, что он порвал «мистические нити», которые связывают человека с истинной церковью и соборностью. Рационалистическая объективность отошла от объективного бытия и сконцентрировалась лишь на мире внутренней субъективности. По мнению Бердяева, рационалистическая философия не в состоянии постичь феномен свободы человеческой личности, тогда как в мистической философии свобода является исходным пунктом развития: «Личность иррациональна для рационалистической философии и всегда разложима и на что-нибудь сводима; пантеистический монизм или атомистический плюрализм оказываются роковым пределами рациональной мысли. Для мистической философии личность изначальна, неразложима, постижима в единственности своего вечного бытия. Рационалистическая философия бессильна решить проблему зла, так связанную с проблемой свободы и личности. Для мистической философии проблема зла разрешима, это ее пробный камень» ${ }^{8}$. С этими рассуждениями связано и обоснование философом особой миссии России в современном мире - России как страны духа живой и конкретной истины.

Особенностью обоснования Бердяевым идеи свободы является то, что он выступает против растворения человеческой личности в обществе. Исходя из такого понимания свободы Бердяев выступает и против нравственного разума в понимании Канта, поскольку любой закон ограничивает человеческую личность, тогда как истинная личность должна быть свободна.

Бердяев отвергает всеобщие законы - как закон необходимости, так и закон целесообразности, но особенно решительно выступает Бердяев против всеобщего в социальной сфере - такой, как власть государства или же коллектива. «Здесь он затрагивает одну из самых острых и больных проблем нашего века, - века тоталитарных режимов, массовых типов общностей, деспотических и нетерпимых к свободе отдельного человека. Здесь - глубокая правда бердяевского неприятия безличной, непреходящее значение заявленного им принципа свободы личности, ценность персонализма. Быть может, нет для XX века темы более насущной, чем тема «человек

8 Там же. С. 29. 
и коллектив», и она как раз является стержневой в творчестве Н.А. Бердяева»

Критикует Бердяев и чрезмерную увлеченность современных обществ идеей прогресса, наукой и материальными аспектами жизни, когда полностью исчезает ощущение смысла жизни, а «абсолютный центр» бытия полностью растворяется в повседневной текучке. Несмотря на впечатляющие успехи точных наук, нельзя поддаваться эйфории позитивизма и пытаться сконструировать законы общественного развития по образу и подобию законов в естественных науках: «Нельзя установить законов истории, так как нельзя построить науку истории по образцу естествознания, которое имеет дело с повторяющимися явлениями и устраняет все индивидуальное. «Научная» теория истории невозможна и обычно выливается в мертвую и пустую дисциплину социологии - этого богословия позитивистов» ${ }^{10}$. Где же выход? Идеи славянофилов подсказывают и здесь верное решение - религиозное сознание способно воспринять и индивидуальное, и универсальное одновременно.

Констатируя состояние современного мира как состояние глубокого кризиса - с одной стороны набирающие силу социалистические идеи о коллективизме и диктатуре пролетариата, а с другой не менее бурно расцветающий материализм и потребительские ценности запада, - Бердяев говорит о наступающих временах «тоски духа», когда ожидается религиозное разрешение всех насущных противоречий в мире.

Сегодня можно отметить тот факт, насколько точно Бердяев определяет состояние современного ему мира - а работа «Философия свободы» была написана в 1911 г. - как некого кануна, перехода к совершенно новому состоянию. По мнению Бердяева, русскому человеку решительно враждебны «мещанство» и «механистические идеалы» Западной Европы. «Европа сгнила», а «монгольский Восток» слишком безличен - и только Россия в состоянии сплотить народы и вывести весь мир на путь постижения истинной свободы духа.

Однако, как показали события последующих лет, «мессианистско-религиозные» чаяния русского народа привели страну не к очищению от пут рабства, самодержавия и варварства, а ввергли страну в фатальную пучину революционных преобразований. Как все-таки печально, что такая сильная вера в духовное здоровье и огромный потенциал русской на-

\footnotetext{
9 Гайденко П.П. Владимир Соловьев и философия Серебряного века. М., 2001. С. 304.

10 Бердяев Н. Философия свободы. М., 2007. С. 169.
}

ции вошла в такое резкое противоречие с реальными фактами истории.

Если же отвлечься от религиозной составляющей философии свободы Бердяева и посмотреть «философское наполнение» его идей, то можно увидеть, что Бердяев в своем понимании свободы стоит очень близко к Шопенгауэру. У Шопенгауэра воля и свобода являются иррациональными началами; так же и Бердяев трактует свободу полное отрицание какой-либо детерминации и подчинения. Отсюда можно сделать вывод, что Бердяев выступает как «антагонист не только Канта, но и общеевропейской этико-религиозной традиции, имеющей два источника - христианство и античную мысль - и основанной на различении добра и зла. Бердяев же хочет создать этику, лежащую «по ту сторону добра и зла», пытаясь углубить и развить аморализм Ницше» ${ }^{11}$.

В трактовке Бердяевым понятия свободы хорошо видны идеи философии романтизма, дионисийское начало и максимализм. В результате соединения этих идей он приходит к выводу, что любой закон и любое подчинение с неизбежностью ведет человека к рабству. Идеи немецких романтиков в сочетании с мыслями Лермонтова и Достоевского и поднимают человеческую личность в философии свободы Бердяева на ступень «по ту сторону добра и зла», где человек обретает свою истинную свободу.

По Бердяеву жизнь человека - это постоянная борьба против порабощающего государства и закономерностей природы - именно так подлинная личность может утвердиться в своей свободе. Личность предполагает исключение себя из подчинения общим закономерностям и само существование такой личности в детерминированном мире является парадоксом.

Именно поэтому личность нельзя определить, пользуясь инструментарием рационального познания: «Рационализм для Бердяева - иллюзия сознания, порожденная социальным приспособлением. [...] Бердяев и Шестов осуществляли экзистенциалистскую критику рационализма. Они противополагали рациональное познание свободе, которая, в свою очередь, интерпретировалась ими как главное свойство личности» ${ }^{12}$. Философ полагал, что разум сковывает как наши эмоции, так и нашу волю. В то время как свой истинный выход свобода получает в человеческом творчестве: "Для философии творчества основным является сознание, что человек

11 Гайденко П.П. Владимир Соловьев и философия Серебряного века. М., 2001. С. 307.

12 Волкогонова О. Бердяев. М., 2010. С. 33. 


\section{Психология и психотехника 7(58) • 2013}

не находится в законченной и стабилизированной системе бытия, и только потому возможен и понятен творческий акт человека. Другое основное положение заключается в том, что творческий акт человека не есть только перегруппировка и перераспределение материи мира [...] В творческий акт человека привносится новое, небывшее, не заключенное в данном мире, в его составе, прорывающееся из иного плана мира, не из вечно данных идеальных форм, а из свободы, не из темной свободы, а из просветительной свободы» ${ }^{13}$.

Одним из главнейших критериев в определении человеческой свободы для Бердяева выступает отсутствие сдерживающих рамок. Согласно христианской догматике, абсолютно свободным может быть лишь бог, тогда как человеку не присуща такая божественная свобода, поскольку человек является творением божьим и греховным существом.

Именно в этом пункте Бердяев расходится с каноническим пониманием Библии, что делает его позицию похожей на критику богословия, предпринятую Ф. Ницше: «Бердяеву чуждо христианское убеждение в том, что источником зла в мире является человек, точнее его грехопадение, и не случайно антропология для него - это христология: в каждом человеке для Бердяева живет не просто образ божий, но сам бог Иисус Христос. По Бердяеву, Христос есть Абсолютный человек, а поскольку Христос - это сын Божий, то и человек есть Сын, а не тварь» ${ }^{14}$. Сам бог действует не через необходимость и не на необходимость, а через свободу и на свободу - бог не принуждает людей познать и признать себя - и именно в этом скрыта «тайна мировой жизни».

Творческая способность человека и выделяет его из причинно-целевой цепи природного мира и ведет его к самоспасению. С помощью творчества человек выходит за пределы мира необходимости и входит в царство свободы. Однако, по мысли Бердяева не детерминизм природного мира является главным врагом свободы личности - объективация является помехой для человека на пути к его свободе. Ранее Бердяев говорил о двойственности человека и о наличии двух миров у человека - мира внутреннего, субъективного и мира внешнего, объективного. Постепенно мы приходим к «религиозным истокам и «религиозным основаниям теории познания.

Это основание и исток необходимо искать в идее Богочеловечества, то есть взаимодействия двух при-

\footnotetext{
13 Бердяев Н. Дух и реальность. М., 2006. С. 505-506.

14 Гайденко П.П. Владимир Соловьев и философия Серебряного века. М., 2001. С. 311.
}

род - свободы, активности, творчества и самой человеческой природы. С этим связана и возможность личной, лично-человеческой философии. Сознание объективирует мир, оно первоначально активно в этой объективации, а потом пассивно в своей зависимости от объективированного мира. Но сознание может вновь проявлять активность в освобождении от власти объективированного мира» ${ }^{15}$.

Так у Бердяева появляются столь популярные в русской религиозной философии понятия «Богочеловечества» и «соборности». По мнению Горбунова, «это был один из пунктов, в котором экзистенциалистские представления Бердяева смыкались с традициями русской религиозной философии. Свойственный экзистенциализму индивидуалистический взгляд на мир (изнутри своего «я») у Бердяева не противостоял пониманию существующих социальных задач [... Бердяев] прямо заявлял: «каждый отвечает за всех», и этот тезис имеет принципиальное значение для русской соборности» ${ }^{16}$. Ниже я еще буду говорить о роли понятий Богочеловечества и соборности в философии Бердяева, а сейчас мне хотелось бы указать на второй смысл его понятия объективации.

Объективация - это не только объективирующая функция нашего сознания, но объективация еще означает и вторжение человека в мир «падший», в «отчуждение и скованность». Таким образом, у понятия объективации можно выделить два следующих смысла: «Она означает падшесть мира, его раздробленность и порабощенность, причем экзистенциальные субъекты, личности превращены в вещи, в предметы, в объекты. Но она означает также акты субъекта, личного духа, направленные на установление связей и сообщений в этом падшем мире» ${ }^{17}$. Падший мир здесь - это бытие, в понимании Бердяева, это скорее неподлинное бытие или даже зло, против которого нужно бороться.

Интересно, что Бердяев как в свои юные годы, так и в зрелом возрасте выступает проповедником этакого «метафизического анархизма» - именно так образно П. Гайденко характеризует персоналистическую философию Бердяева. По ее мнению пафосом философии свободы Бердяева было низвержение всякого объективного установления и объективного порядка. А посему «идея социальной революции, которая призвана устранить капитализм, ненавистную Бердяеву и как аристократу,

15 Бердяев Н. Философия свободного духа. М., 1994. С. 245.

16 Горбунов В. Идея соборности в русской религиозной философии (пять избранных портретов). М., 1994. С. 83.

17 Бердяев Н. Философия свободного духа. М., 1994. С. 389. 


\section{Социальные страсти}

и как представителю художественной богемы «власть мещанства», - вот что объединяло его с марксизмом, так же как и страстное стремление „не объяснить, а изменить мир“»18.

Это очень существенный момент как в философской позиции, так и в мировосприятии Николая Бердяева. Что это - идеализм и максимализм, являющиеся, по мнению многих западных мыслителей, отличительными чертами типично русского менталитета? Мессианизм в философии? Отголоски религиозного фанатизма в русской религиозной философии, столь сильно повлиявшей на становление и развитие бердяевских идей? Или же это просто следствие глубоких социальных катаклизмов кануна XX в., нашедших свое отражение в трудах Бердяева? Весь этот круг вопросов требует своего детального изучения, которое выходит далеко за рамки данной публикации. Сейчас же мне просто хотелось зафиксировать такой важный момент как «бунтарскую» или же «анархистскую» устремленность в мышлении и философии Бердяева.

По мысли Бердяева, философия свободы начинается со свободного акта, до которого существование бытия просто невозможно: «Когда в основу кладется бытие и признается примат бытия над свободой, то все им детерминировано, детерминирована и свобода, но детерминированная свобода не есть свобода. Но возможен другой тип философии, который утверждает примат свободы, творческого акта над бытием. Только второй тип благоприятен свободе» ${ }^{19}$. Как отмечает А. Гулыга, в философии Бердяева можно выделить три разновидности понятия свобода: «Помимо первичной, формальной свободы «по ту сторону добра и зла», есть два варианта содержательной свободы, один - творить зло («дьявольская свобода»), другой - творить добро («высшая», божественная свобода). Любовь есть содержание такой свободы. Когда Бердяева называли «пленником свободы», речь шла именно о высшем ее варианте» ${ }^{20}$.

В своем определении свободы как метафизического начала Бердяев опирается, прежде всего, на иррационалистическую традицию и интуитивизм в духе Бергсона. Здесь мы сразу видим различие с рационалистической устремленностью другого русского мыслителя - Бориса Чичерина. И хотя для Чичерина при определении понятия идеи свободы также очень

\footnotetext{
18 Гайденко П.П. Владимир Соловьев и философия Серебряного века. М., 2001. С. 314.

19 Бердяев Н. Дух и реальность. М., 2006. С. 622.

20 Гулыга А.В. Творцы русской идеи. М.: Молодая гвардия, 2006. C. 161
}

важна была роль метафизики в философии, но именно «философской» или же «рационалистической» метафизики, а не богословского откровения. Бердяев в противоположность к идеям Чичерина - полагает, что детерминизм и рациональное мышление ограничивают свободу и убивают сам ее дух - ведь свобода, по его глубокому убеждению есть дух, а не материальное бытие в природном, жестко детерминированном мире.

Поэтому для понимания и определения феномена свободы нужно действовать не в рамках рационалистической традиции, а опираться на данные нашего духа и внутреннего опыта. Только тогда можно понять утверждение Бердяева о том, что проблема свободы есть проблема творчества.

В определении идеи свободы нужно уйти от ее статического понимания и понимать ее только динамически. Ведь существует «судьба свободы в мире, экзистенциальная диалектика свободы в мире. Свобода может переходить в свою противоположность. Рабство может быть порождением ложно направленной свободы. Наиболее общее определение свободы, обнимающее все частные определения, заключается в том, что свобода есть определение человека не извне, а изнутри, из духа. Духовное начало в человеке есть истинная свобода, а отрицание духа, додуманное до конца, - неизбежно есть отрицание свободы» ${ }^{21}$. Поэтому материализм и ведет с неизбежностью к отрицанию свободы, говорит Бердяев.

Однако вопрос о внутренней свободе человека гораздо сложнее, чем это может показаться на первый взгляд, оговаривается Бердяев. Ведь человек может подчиняться не только внешним обстоятельствам, но и низменным инстинктам своей собственной души. Именно в этом коренится причина того, что революции не приводят к созданию нового свободного общества - в революциях бывает меньше всего свободы, - утверждает Бердяев в своей поздней работе «Царство Духа и царство Кесаря», вышедшей впервые в Париже в 1951 г.

Здесь наглядно сказывается горький опыт, вынесенный им из революции 1917 г. По мнению Бердяева, истинной свободы мы достигаем не тогда, когда у нас есть ситуация выбора, это есть, так сказать, только «формальный выбор». Истинная свобода достигается человеком лишь тогда, когда человек совершает сам акт выбора. Поэтому, хотя свобода и является внутренней творческой энергией человека, но свобода не является лишь внутренней причинностью - свобода стоит вне причинно-

21 Бердяев Н. Дух и реальность. М., 2006. С. 263. 


\section{Психология и психотехника 7(58) • 2013}

следственных отношений: «Причинные отношения находятся в объективированном мире феноменов. Свобода же есть прорыв в этом мире. Свобода приходит из иного мира, она противоречит закону этого мира и опрокидывает его» ${ }^{22}$. Кроме того, свобода это не право, а обязанность.

В этом пункте Бердяев критикует мыслителей западной англосаксонской либеральной направленности, которые понимают свободу именно как право, а не как обязанность индивида. Такое понимание свободы для либеральных мыслителей означает «легкость» и «отсутствие стеснений», а это, в свою очередь, ведет к тому, что свобода становится привилегией только лишь господствующих классов, утверждает Бердяев. В действительности же свобода предполагает сопротивление, она показывает нам силу и волю человека.

В очередной раз Бердяев предостерегает нас от отождествления абсолютной свободы с анархией и вседозволенностью и говорит, что в революциях человеческие массы стремятся вовсе не к свободе. Ведь для того, чтобы человек боролся за свободу, необходимо, чтобы у него было истинное понимание свободы и внутреннее освобождение от рабского состояния. Поэтому, для Бердяева свобода скорее аристократична, чем демократична.

В развитых буржуазных обществах, проповедующих принцип «laissez faire, laissez passer», господствует статическая свобода, свобода status quo, что, по мнению Бердяева, является кесаревым принципом. А нужно утверждать динамическое понимание свободы, т.е. свободу творческого движения. В социальной жизни можно выделить различные ступени свободы. К примеру, свобода увеличивается по мере приближения к духу и уменьшается по мере приближения к материи, говорит Бердяев. Дух есть свобода, а материя - это необходимость. Однако в современных западных обществах очень часто свобода мысли и духа отрицается, а на ее место ставится экономическая свобода: «Абсолютная свобода в экономической жизни, т.е. совершенная ее автономия, и была системой „laisser faire, laisser passer“, т.е. капиталистической системой. Она ставит в очень тяжелое положение огромные массы человечества. Это делается источником эксплуатации. Поэтому экономическая свобода должна быть ограничена, ограничена во имя свободы же» ${ }^{23}$. И если, порой, возможной и оправданной могут быть политическая или экономическая диктатуры, то духовная и интеллектуальные диктатуры совершенно недопустимы, утверждает Бердяев.

Эволюция взглядов Бердяева была такова, что в своих ранних работах он трактовал онтологию как монадологию и понятие бытие сначала не несет в себе ничего отрицательного. Однако постепенно он приходит к мысли необходимости «освобождения» от мира причинности. В его поздних трудах уже возникает идея о противоположности свободы и бытия, а само понятие бытия начинает характеризоваться как «падший мир». При этом свобода стоит как над миром природной детерминации, так и над богом - свобода коренится в «небытии», имеющим более высокий статус чем статус бога.

Именно поэтому Бердяев со временем начинает интересоваться идеями Якова Беме о «ничто» как о той первооснове, из которой возникает все, включая и самого Бога. Отсюда мысли Бердяева об абсолютности свободы, о свободе как источнике космоса и логоса: «Свобода не только первичнее бытия, она, по Бердяеву, определяет собой и путь бытия» ${ }^{24}$. Такая позиция с неизбежностью приводит Бердяева к тому, что он ставит человека в своей свободе выше самого Бога.

Бердяев говорит о том, Бог уже давно «умер» и «заменен» моралью. Такие умонастроения сегодня часто связываются с самим духом эпохи русского Серебряного века, эпохи кануна грандиозных социальных, политических и экономических перемен в России. И хотя в целом Бердяев восхваляет духовную свободу человека, в своей социальной философии он заходит все же слишком далеко, когда отрицает любые формы государственности, поскольку государство порабощает личность и отнимает у нее свободу.

Именно поэтому к ряду идей Бердяева следует относиться «трезво и реалистически, не поддаваясь искушению утопизма, максимализма и экстремизма» ${ }^{25}$ и не впадая в соблазн «обожествления» человека. Бердяев как человек, проживший все свои зрелые годы в эмиграции, настойчиво пытался разобраться в «межрегиональных» культурных различиях между Россией и Западной Европой, и это, в свою очередь, привело его к подчеркиванию особого духовного статуса России в мире.

22 Там же. С. 624.

23 Там же. С. 629.

24 Гайденко П.П. Владимир Соловьев и философия Серебряного века. М., 2001. С. 317.

25 Там же. С. 322. 


\section{Список литературь:}

1. Бердяев Н. Самопознание. Опыт философской автобиографии. Париж, 1949. 332 с.

2. Бердяев Н. Философия свободного духа. М., 1994.

3. Бердяев Н. Дух и реальность. М., 2006. 679 с.

4. Бердяев Н. Философия свободы. М., 2007. 701 с.

5. Бердяев Н. Избранные труды. М., 2010. 648 с.

6. Волкогонова О. Бердяев. М., 2010. 390 с.

7. Гайденко П.П. Владимир Соловьев и философия Серебряного века. М., 2001. 472 с.

8. Горбунов В. Идея соборности в русской религиозной философии (пять избранных портретов). М., 1994.180 с.

9. Гулыга А.В. Творцы русской идеи. М., Молодая гвардия, 2006. 316 с.

10. Филиппова Т. Николай Александрович Бердяев // Волкогонова О. Бердяев. М., 2010.

\section{References (transliteration):}

1. Berdyaev N. Samopoznanie. Opyt filosofskoy avtobiografii. Parizh, 1949. $332 \mathrm{s.}$

2. Berdyaev N. Filosofiya svobodnogo duha. M., 1994.

3. Berdyaev N. Duh i real'nost'. M., 2006. 679 s.

4. Berdyaev N. Filosofiya svobody. M., 2007. $701 \mathrm{~s}$.

5. Berdyaev N. Izbrannye trudy. M., 2010. $648 \mathrm{s.}$

6. Volkogonova O. Berdyaev. M., 2010. 390 s.

7. Gaydenko P.P. Vladimir Solov'ev i filosofiya Serebryanogo veka. M., 2001. 472 s.

8. Gorbunov V. Ideya sobornosti v russkoy religioznoy filosofii ( pyat' izbrannyh portretov). M., 1994. $180 \mathrm{~s}$.

9. Gulyga A.V. Tvorcy russkoy idei. M., Molodaya gvardiya, 2006. 316 s.

10. Filippova T. Nikolay Aleksandrovich Berdyaev // Volkogonova O. Berdyaev M., 2010. 